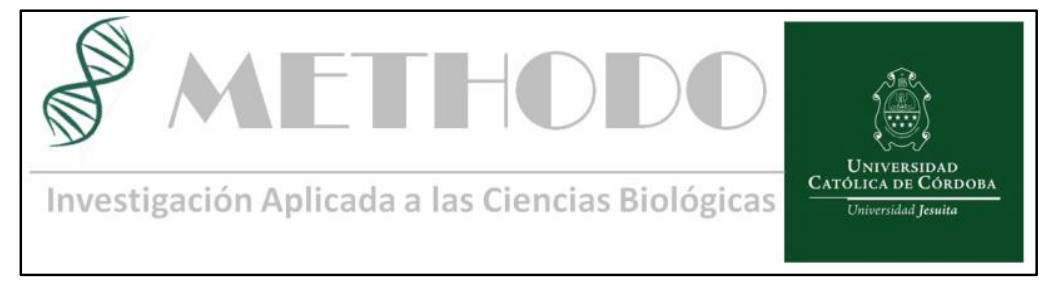

\title{
Correlación de escalas de riesgo en hemorragia digestiva alta no variceal con mortalidad, resangrado y necesidad de intervención *
}

\section{Correlation of risk scales in non-variceal upper gastrointestinal bleeding with mortality, rebleeding and need for intervention *}

*Trabajo Presentado en las XIV Jornadas de Investigación de la Clínica Universitaria Reina FabiolaOctubre de 2017

Lucero $\mathrm{PD}^{1}$, Gutiérrez Magaldi I ${ }^{1}$, Camporro $\mathrm{F}^{1}$, Bertorello $\mathrm{MN}^{1}$.

\section{Introducción:}

La hemorragia digestiva alta (HDA) es una urgencia frecuente. ${ }^{1}$ La evaluación inicial con escalas pronósticas pre y postendoscópicas es fundamental para conocer los pacientes con mayor riesgo de complicaciones y con ello decidir la realización de una intervención de urgencia. ${ }^{2-5}$

Hipótesis: Las escalas pronósticas pre y postendoscópicas validadas para HDA no variceal predicen mortalidad, resangrado y necesidad de intervención en nuestra población de pacientes.

Objetivos. Primarios. Evaluar la correlación de las escalas pronósticas preendoscópicas Blatchford y Rockall y las post endoscópicas Forrest y Rockall con mortalidad, resangrado y necesidad de intervención intra-hospitalaria en HDA no variceal. Evaluar la concordancia entre los resultados de las escalas pre y postendoscópicas. Secundarios. Describir las causas más frecuentes y la mortalidad de HDA no variceal.

\section{Pacientes y Métodos.}

Estudio observacional, retrospectivo, de pruebas diagnósticas. Se analizaron los datos de todos los pacientes mayores de 18 años internados por HDA no variceal, de enero de 2012 a agosto de 2015, mediante revisión de historias clínicas e informes endoscópicos en la Clínica Universitaria Reina Fabiola, Córdoba, Argentina.

Análisis Estadístico: Para evaluar la asociación de las escalas con complicaciones de HDA no variceal (mortalidad, resangrado y necesidad de intervención) se realizó una tabla de $2 \times 2$ con un test de Chi cuadrado. Igualmente se procedió para evaluar la concordancia entre los resultados de las escalas. Las causas de HDA no variceal y la mortalidad se proporcionan como $\mathrm{N}(\%)$.

\section{Resultados.}

En el estudio se incluyeron 65 pacientes. En 37 (57\%) pacientes se realizó algún tipo de intervención, la frecuencia de re-sandrado fue de $4(6.2 \%)$ y la mortalidad de $2(3.1 \%)$ de los casos. No se encontró significancia estadística de las escalas para predecir resangrado, excepto la escala de Forrest $(\mathrm{p}=0.035)$. La asociación para mortalidad tampoco fue significativa, excepto la escala de Forrest $(\mathrm{p}=0.036)$. La asociación de las escalas con la necesidad de intervención fue estadísticamente significativa, Glasgow Blatchford $\quad(\mathrm{p}=0.001), \quad$ Rockall pre endoscópico $\quad(\mathrm{p}=0.036)$, Rockall post endoscópico $(\mathrm{p}=0,001)$ y Forrest $(\mathrm{p}=0.01)$. En la correlación de las categorías de riesgo de las distintas escalas, hay diferencias estadísticamente significativas entre la escala 
de Glasgow Blatchford y las escalas Rockall pre y post endoscópicas ( $\mathrm{p}=0.001, \mathrm{p}=0.001$; respectivamente). En la correlación de las categorías de las escalas post endoscópicas, Rockall y Forrest, también se observaron diferencias estadísticamente significativas $(\mathrm{p}=0.034)$. Por el contrario, la correlación de las categorías de riesgo de la escala de Forrest no mostró diferencias significativas con las categorías de las escalas pre endoscópicas, Glasgow Blatchford y Rockall ( $\mathrm{p}=0.714$, $\mathrm{p}=0.081$; respectivamente). Entre las causas de HDA no variceal, la gastritis erosiva y la úlcera péptica fueron las de mayor prevalencia.

\section{Conclusiones.}

Las escalas analizadas no demostraron ser útiles para predecir resangrado y mortalidad en nuestra población, excepto la escala de Forrest. Todas las escalas son útiles para predecir la necesidad de algún tipo de intervención mostrando su importancia para optimizar los recursos sanitarios.

\section{Introduction.}

High digestive haemorrhage (HDA) is a frequent emergency. ${ }^{1}$ The initial evaluation with pre and postendoscopic prognostic scales is fundamental to know the patients with greater risk of complications and with this, decide to perform an emergency intervention. ${ }^{2-5}$

Hypothesis.

The pre and postendoscopic prognostic scales validated for non-variceal HDA predict mortality, rebleeding and need for intervention in our patient population.

Objective: To evaluate the correlation of Blatchford and Rockall preendoscopic prognostic scales and post-endoscopic Forrest and Rockall with mortality, rebleeding and need for in-hospital intervention in nonvariceal HAD.. To evaluate the concordance between the results of the pre and postendoscopic scales. Describe the most frequent causes and non-variceal HDA mortality.

\section{Patients and Methods.}

Observational, retrospective study of diagnostic tests. We analyzed the data of all patients older than 18 years admitted to nonvariceal HDA, from January 2012 to August 2015, by reviewing clinical records and endoscopic reports at the Clínica Universitaria Reina Fabiola.
Statistical analysis To evaluate the association of scales with non-variceal HDA complications (mortality, rebleeding and need for intervention), a 2 × 2 table was performed with a chi square test. We also proceeded to evaluate the concordance between the results of the scales. The causes of non-variceal HDA and mortality are provided as $\mathrm{N}(\%)$.

\section{Results.}

The study included 65 patients. In 37 (57\%) patients, some type of intervention was performed, the frequency of re-shedding was $4(6.2 \%)$ and the mortality rate was $2(3.1 \%)$ cases. No statistical significance was found for scales to predict rebleeding, except Forrest's scale $(\mathrm{p}=0.035)$. The association for mortality was also not significant, except for the Forrest scale $(\mathrm{p}=0.036)$. The association of the scales with the need for intervention were statistically significant, Glasgow Blatchford $(\mathrm{p}=0.001)$, Rockall preendoscopic $(\mathrm{p}=$ 0.036), Rockall post endoscopic $(\mathrm{p}=0.001)$ and Forrest $(p=0.01)$. In the correlation of the risk categories of the different scales, there are statistically significant differences between the Glasgow Blatchford scale and the Rockall scales pre and post endoscopic $(\mathrm{p}=0.001, \mathrm{p}=$ 0.001 , respectively). In the correlation of the categories of the post endoscopic scales, Rockall and Forrest, statistically significant differences were also observed $(\mathrm{p}=0.034)$. On the contrary, the correlation of the risk categories of the Forrest scale did not show significant differences with the categories of the pre-endoscopic scales, Glasgow Blatchford and Rockall ( $\mathrm{p}=0.714, \mathrm{p}=0.081$, respectively). Among the causes of nonvariceal HDA, erosive gastritis and peptic ulcer were the most prevalent.

\section{Conclusions.}

The scales analyzed did not prove to be useful for predicting rebleeding and mortality in our population, except for the Forrest scale. All scales are useful for predicting the need for some type of intervention showing its importance for optimizing health resources.

\section{Bibliografía}

1. Manrique MA, Hernández Velázquez NN, Chávez García MA y Col. Comparación de dos escalas pronosticas en hemorragia gastrointestinal superior no variceal. Rev Hosp Jua Mex 2010; 77 (2): 112-115. 
Lucero PD, Gutiérrez Magaldi I, Camporro F, Bertorello MN. Correlación de escalas de riesgo en hemorragia digestiva alta no variceal con mortalidad, resangrado y necesidad de intervención

2. Stanley AI. Update on risk scoring systems for patients with upper gastrointestinal haemorrhage. World J Gastroenterol. 2012 Jun 14;18(22):273944

3. Cebollero-Santamaria F, Smith J, Gioe S et al. Selective outpatient management of upper gastrointestinal bleeding in the elderly. Am J Gastroenterol 1999; 94: 1242-1247.

4. Sultan L. Glasgow-Blatchford risk scoring in upper GI bleed. BetsBETs, 2011

5. Winograd Lay R, Infante Velázquez M, Guisado Reyes Y, Angulo Pérez O, González Barea I, Williams Guerra E. Escalas de predicción en el pronóstico del paciente con hemorragia digestiva alta no varicosa. Rev Cubana Med Mil. 2015;44 (1):73-85.

Palabras claves: HEMORRAGIA DIGESTIVA ALTA NO VARICEAL, ESCALA ROCKALL, GLASGOW, BLATCHFORD, FORREST.

Keywords: NON-VARICEAL UPPER GASTROINTESTINAL BLEEDING - ROCKALL SCALE GLASGOW BLATCHFORD FORREST

${ }^{1}$ Servicio de Clínica Médica. Clínica Universitaria Reina Fabiola, Universidad Católica de Córdoba, Argentina. Correspondencia: Pablo Lucero. Clínica Universitaria Reina Fabiola. Oncativo 1248 X5004FHP- Córdoba, Argentina. e-mail: drpablolucero@gmail.com 